\title{
THE PERSONALITY TRAITS OF EMPLOYEE OF STATE EMPLOYMENT SERVICE OF UKRAINE THAT AFFECT THEIR DESIRE TO SELF-DEVELOPMENT AND THE MOTIVATION OF ACHIEVEMENT
}

\section{Kateryna Kalenichenko ${ }^{1}$ Olena Vlasova ${ }^{2}$}

DOI: https://doi.org/10.30525/978-9934-588-15-0-123

Abstract. The employees in the citizens' counseling sector are under constant pressure, increasing demands and challenges, as to the opportunities of getting job. The article analyzes recent research and publications within the framework of basic psychological approaches to determining the essence of the problem of personal development and motivation achievement of inspectors of the State Employment Service of Ukraine. In total, 106 students from the Institute of Training of the State Employment Service of Ukraine, who are employees of the State Pedagogical Institute of the City of Kyiv, participated in the study and underwent retraining in order to obtain the qualification of a psychologist. The purpose of this research is to identify the relationship between the personal dimensions of the employee of the State Employment Service of Ukraine and his/her desire for self-development, motivation for achievement. According to the purpose the following tasks have been set:

1) describe the portrait of the employee (inspector) of the SESU;

2) identify the need for personal development of employees of the SESU;

3) establish interdependence between motivation achievement and the desire to self-development;

4) investigate the relationship of personality measurements of the personality of the employee of the SESU with his/her motivation achievement.

Research methods: Five-Factor Personal Questionnaire, SelfDevelopment Readiness Test, VL Pavlov, Diagnosis of Achievement

\footnotetext{
${ }^{1} \mathrm{PhD}$ Student of Psychology Faculty, Kyiv National Taras Shevchenko University, Ukraine

${ }^{2}$ Doctor of Sciences in Psychology, Professor, Head of Developmental Psychology Department, Kyiv National Taras Shevchenko University, Ukraine

(C) Kateryna Kalenichenko, Olena Vlasova
} 
Motivation. The calculation of the correlation coefficients and all the necessary intermediate data was performed by computer processing, which was serviced by the IBM SPSS Statistics 20 software package. The results show that SESU employees are driven by the motive of avoiding failure, not the motive for success, which is associated with a low desire for selfdevelopment. We have received a personal profile of an employee of the State Employment Service of Ukraine. These sociable people are open to communicating with an easy attitude to life. They are quite impulsive, so they work worse in stressful situations. They do not like to burden themselves with work, but they do it honestly. They do not like competition, tend not to be persistent in achieving their goal and may have low self-esteem. Easy to learn, but not sufficiently serious about systematic scientific activity, sensitive to incentive. Positive links were found between the motivation development of the employees of SESU and their personal dimensions: Conscientiousness and Agreeableness. Expressiveness also correlates with the desire to self-development. The interdependence between the motivation of achievement and the desire for self-development has been the strongest.

\section{Introduction}

The third millennium was marked by inevitable transformations in all spheres of life of Ukrainian society. The changes taking place in the present-day context require not only updating of traditional schemes of state-government relations, but also filling with new content of professional activity of civil servants in the exercise and realization of state power, which first of all actualizes the issue of professional competence of specialists in this field. Each high-quality specialist plays an important role in the management and functioning of the organization. Splicing the professional suitability of the organization's worker, including educational, for the vacant position is an urgent task, as every year it is becoming increasingly difficult to attract a "qualitative" specialist from an external labor market. Modern conditions require a specialist not only a high level of professionalism, but also his constant willingness to enrich and update his knowledge, skills and abilities. Therefore, the effective functioning of the management system in any organization depends not only on its organizational structure, external factors, but also on the personal characteristics of professionals and the characteristics of professional activity. An important factor in improving the 
efficiency of the State Employment Service of Ukraine is the development of the necessary competencies and personal qualities of civil servants, especially their staff reserve [8, p. 31-45].

Regarding to persons working in the education sector (teachers, instructors, pedagogues, etc.), the laws of Ukraine (2007) "On education", "On higher education", in "Conceptual principles of development of pedagogical education of Ukraine and its integration into the European educational space" the requirements for the quality of professional training of future teachers, which should ensure the personal and professional development of the future teacher on the basis of personal pedagogy are elucidated [22]. That is why the employee of the State Employment Service of Ukraine should be able to actively perceive new, to continuous personal and professional self-improvement.

\section{The personality of a civil servant}

The solution of the problem of professional development of employees of the State Employment Service should begin with the study of its primary structure - the person as a personality. In the writings of researchers There are many definitions of the personality in the writings of the researchers. It is related to the polysemy of this concept. I.S. Kohn (1984) considers that, on the one hand, the concept of "personality" designates a particular individual as a subject of activity in the unity of his/her individual properties (single) and social roles (general). On the other hand, a person is understood as a socially defined individual who integrates socially significant traits created in the process of direct and indirect interaction with other people, which makes him/her a subject of work, cognition and communication [12, p. 470]. Summarizing well-known approaches, we can determine that a personality is a specific person, taken in the system of his/her stable socially determined psychological characteristics, which are manifested in public relations and relationships, determine his/her moral actions and are essential for himself/ herself and others.

Analysis of scientific achievements reflected in theoretical and empirical studies by V. Averyanov, V. Bodrov, L. Voronko, D. Dzvinchuk, S. Zagorodniuk, L. Karamushka, O. Kozievsky, V. Kozlovsky, V. Malinovsky, N. Nizhnik, I. Ninyuk, L. Orban-Lembrik, M. Pirin, V. Skuratovsky, S. Khadzhiradieva and others national researchers make 
it possible to distinguish the tendency which is to search and scientifictheoretical substantiation of theoretical and methodological foundations of professional development and improvement of important qualities and skills of civil servants. Theoretical analysis of the scientific works of P. Bespalov, O. Bodalyov, V. Bodrov, A. Derkach, V. Zazikin, A. Markova, O. Moskalenko, M. Pirin, V. Rebkalo, V. Shadrikov made it possible to define the notion of professionally important qualities (PIQ), which occupy a special place in the formation of the psychological system of activity. These are "the internal psychological characteristics of the subject, which reflect the external specific influences of factors of a particular work process, which act in the form of professional requirements for personality" [2, p. 96]. PIQs reflect the main characteristics of the personality structure that determine the psychological foundations of the system of activity: motivational-value, cognitive, psychomotor, emotional-volitional and others. Theoretical analysis of modern scientific literature makes it possible to conclude that all personal traits required for the professional activity of a public servant can be conditionally divided into the following groups:

1. Psychological characteristics that are part of the fitness for the profession - characteristics of memory, thinking, mental states, attention, emotional and volitional characteristics, etc.

2. Psychological characteristics related to attitude and performance of the activity - communicativeness, initiative, perseverance, commitment, etc.

3.Psychological characteristics related to self-attitude - self-control, ability to manage their emotions, self-criticism, self-evaluation of their activity [14, p. 20].

Peculiarities of the professional activity of civil servants are characterized by specific integral factors that cover such professionally important qualities of the individual as adaptive mobility, emotional leadership, ability to integrate social functions (roles), contact, stress resistance, desire for dominance.

In our study, it is supposed to consider the personality of an employee of the state employment service of Ukraine, who receives the first higher education in the specialty of "psychology". That is, a person undergoing a stage of socialization, whose purpose is to obtain the necessary competencies to work and provide services to the unemployed.

According to the appointment of the State Employment Service, it has a number of functions, such as: analysis and forecast of labor supply and 
demand; advising citizens (business owners, institutions and organizations or bodies authorized by them who contact the employment service) on the possibility of obtaining a job and providing labor; requirements for the profession; assisting citizens in the selection of decent work and owners of enterprises, institutions and organizations or their authorized bodies in the selection of necessary workers, etc.

Also, one of the important functions of employees of the state employment service is psychological support for the unemployed. Modern HR management of the public employment service, like any other public service, must meet the mandatory requirements (modules of personnel competence), namely:

- the employee of the Service must possess methods of methodical competence, or have the ability to perceive and interpret information, structure problems, system thinking, understand and use organizational and social connections that arise in the course of work of the team;

- the employee of the Service must be socially competent; have the ability to communicate, collaborate, resolve conflicts, the ability to manage employees and maintain external communications [3, p. 26-30].

The duties of specialists in the public employment service are not only to fulfill certain functional responsibilities, but also to provide appropriate social services that must meet the conditions of modern production and management: a specialist SESU must have modern information technology; be able to adapt to the rapid changes of the labor market, to perceive and introduce new forms of work; be prepared to make his/her own decision in order to achieve the strategic goals of the organization.

Thus, the professional psychological qualities of an employee (inspector) of the State Employment Service arising from his / her functions should be related to communicativeness, plasticity of behavior, ability to work collectively and availability of organizational abilities, creativity and developed emotional intelligence.

\section{Achievement motivation and personal development}

Personal development plays an important role in the possession of professional competences. Thomas (2014) argues that personal development is determined by an awareness of the desire to achieve growth through the expansion of one's knowledge and self-awareness in order to improve one's 
personal skills. This indicates that personal development is a process in which one seeks to improve. Beausaert, Segers, and Gijselaers (2011) add that personal development should not be only improved but also supported. That is, it is supposed constant improvement of the person's ability to master himself/herself. Personal development is all that people learn about themselves, their strengths and weaknesses. All previous definitions show that the concept of personal development is focused on their own skills and experience. However, Hughes and Youngson (2009) write about the role of seeking acceptance, awareness, and understanding of the process of personal development. This context speaks to the importance of the desire to know oneself in the process of personal development.

In national scientific literature of recent years in respect of the acmeological approach, a number of works devoted to the study of the substantive side of the highest acmeological achievements of individuals and organizations has appeared [21]. A special attention should be turned on the experience of the Humanitarian (Arts) Lyceum under Kyiv national Taras Shevchenko University, where in 2010-2016, in accordance with the plan of scientific researches of MES of Ukraine an experimental work on the topic: "Development and establishment of the model of acmeological educational institutions" was carried out (prof. Sazonenko, G.S. is a scientific supervisor, prof. Vlasova, O.I. is a scientific tutor). The research program included the determination of the influence of acme-management, acmeological space of the Lyceum and acmeological education on the formation of different kinds of competences and personality characteristics of high school students.

However, not every personality strives for self-development. In the view of Frizin M.A. (2016), personal autonomy, accepting situations of uncertainty, novelty as resources for self-change, self-improvement are based on psychological readiness for self-development. That is, for selfdevelopment there must be certain conditions and motivation for success.

On the other hand, we should not forget about motivation factors of personal and professional development. Motivation is defined as the willingness to exert high levels of effort to reach organizational goals, conditioned by the ability of these efforts to satisfy some individual needs, as motivating factors are: salary, advancement in career, workplace safety, work contracts, working conditions, organizational culture, leadership 
in working organizations, the level of responsibility at work (degrees), bonuses, etc. According to prof. Ermira Qosja (2015), it is the particular qualities of performance management. It would be wise to mention here that sincere concern for people and their welfare is the most valuable approach of encouraging them to achieve good results. Ermira Qosja's research focuses on salary as motivational factors in the performance of civil servants in public local administration. Other motivation is possibility to work from home and her very large application brings question marks for salary comparing with the hours. Flexible work hour is also an important factor as the author points that by linking rewards to employee performance, you can increase employee motivation and achieve winning results [20, p. 15-24].

According to Murray (1938), achievement motivation is expressed in the need to overcome obstacles and achieve high performance in work, to self-improve, compete with others and advance them, to realize their talents and thus to increase self-esteem. Achievement motivation is one of the varieties of activity motivation associated with the individual's need to succeed and avoid failure. Formation of motivation to succeed or to avoid failure depends on the conditions of education and environment, as well as:

1) personal standards (assessments of subjective probability of success, subjective difficulty of the task);

2) attractiveness of self-esteem (attractiveness for the individual's personal success or failure in this activity);

3) the individual benefits of the type of attribution (attribution of responsibility for success or failure to oneself or surrounding circumstances).

To highlight the problem of connection between motivation for work and personal development, personality type and personal development, one should pay attention to the research by Irina Tamminga \& Elsbeth de Boer "Employees' desire for personal development in the front office of the InterContinental Miami" [18, p. 99-103]. The data showed that the relationship between motivation to work and personal development was the strongest (0.54). As to personality type, such a factor as "diligence" showed an impact on personal development. There is no connection between the time of employment and the need for personal development.

Summarizing, one can say that the motive for success is the desire of a person to succeed in various activities and communication. The motive for avoiding failure is the relatively persistent desire of a person to avoid 
failure in life situations related to the evaluation of other people the results of his/her performance and communication. It is also important to note that motivational phenomena, repeatedly repeated, later become traits of a person's personality.

\section{Organization and methodology of personality study of an employee of the State Employment Service of Ukraine}

Based on the theoretical background, we see that the concept of motivation achievement is closely related in content to personal development. But the relationship between the motivation variables of achievement and the factors of personality of an employee of the State Employment Service of Ukraine is still unknown. That is why the purpose of this exploratory study was to describe a portrait of the employee of the State Employment Service of Ukraine. In addition, the study examined the factors of personality of an employee of SESU, which are related to their motivation achievement, the desire to develop himself/herself. To achieve the goal of the study, you must answer the questions:

- To what extent do employees of the State Employment Service of Ukraine feel the need for personal development?

- What is the relationship between the motivation of achievement and the need for personal development of employees?

- How do the employee's personal dimensions connect to their motivation of achievement?

Thus, the study specifically focused on correlation analysis. This is a type of intelligence research that analyzes the relationships between variables.

Participants and research procedure.

The study was attended by the 106 students of the Institute of Personnel Training of the State Employment Service of Ukraine, who are the workers of the State Employment Service of Ukraine in Kyiv and took a course of retraining in order to obtain a qualification of a psychologist. Among them there are 98 women and 8 men aged from 19 to 43 years old $(M=30.89$; $\mathrm{SD}=7.74)$. This sample composition is due to the need to collect data during the educational process and the possibility of further corrective work with these individuals. $76 \%$ of these people do not have higher education (see Table 1), more over, 62\% are working in the PESU, 26\% are having part-time employment and $11 \%$ are not working (see Table 2). 
Table 1

The education of respondents

\begin{tabular}{|l|c|c|c|c|}
\hline & Frequency & Percentage & $\begin{array}{c}\text { Valid } \\
\text { percentage }\end{array}$ & $\begin{array}{c}\text { Accumulated } \\
\text { percentage }\end{array}$ \\
\hline $\begin{array}{l}\text { accountant } \\
\text { economist }\end{array}$ & 8 & 7,5 & 7,5 & 7,5 \\
\hline $\begin{array}{l}\text { master of } \\
\text { manicure }\end{array}$ & 8 & 7,5 & 7,5 & 15,1 \\
\hline $\begin{array}{l}\text { without } \\
\text { education }\end{array}$ & 76 & 71,7 & 71,7 & 86,8 \\
\hline travel agent & 8 & 7,5 & 7,5 & 94,3 \\
\hline florist & 4 & 3,8 & 3,8 & 98,1 \\
\hline photographer & 2 & 1,9 & 1,9 & 100,0 \\
\hline Total & 106 & 100,0 & 100,0 & \\
\hline
\end{tabular}

The survey participants were offered a questionnaire focused on identifying the objective characteristics of their life (age, gender, place of residence, education, profession, previous and current professional activity, etc.) and a battery of tests to determine personality measurements and achievement motivation. Due to paper and pencil surveys, the order of questionnaires and tests was fixed and identical for all participants.

Table 2

\section{Employment of respondents}

\begin{tabular}{|l|c|c|}
\hline \multicolumn{1}{|c|}{ Frequency } & Percentage & Valid \\
\hline does not work & 12 & 11,3 \\
\hline works & 66 & 62,3 \\
\hline part-time & 28 & 26,4 \\
\hline Total & 106 & 100,0 \\
\hline
\end{tabular}

Research methods.

A five-factor personal questionnaire, better known as the Big Five (5PFQ), was adapted and standardized by AB Khromov in 1999 [9]. The test-questionnaire consists of 75 paired, opposite in value, statements that characterize human behavior. Incentive material has a five-point rating scale $(-2 ;-1 ; 0 ; 1 ; 2)$ to diagnose the severity of each of the five main factors: Extraversion (extraversion - introversion); Agreeableness 
(commitment - isolation); Consciousness (self-control - impulsiveness); Neuroticism (emotional instability - emotional stability); Openness (expressiveness - practicality). Also, each of the major factors has five subfactors that clarify the content of the main one. This technique was chosen to describe a portrait of an employee of the State Employment Service of Ukraine and to determine the employee's personal dimensions.

Self-development readiness test by VL Pavlov [16, p. 30-33]. This test is intended to determine the readiness for self-development by the presence and impression of two components: motivational (I want to know myself) and operational (I can self-develop). The test contains 14 judgments that must be answered 'yes' or 'no'. The obtained values were transferred to the graph: horizontally deferred the value of WKM ("I want to know myself"), and vertically - the value of CDM ("I can develop myself "). In two coordinates, they marked on the graph a point that "falls" in one of the squares: A - "I can develop myself", but "I do not want to know myself"; B - "I can develop myself" and "I want to know myself"; In - "I cannot develop myself" and "I do not want to know myself"; D - "I can not develop myself", but "I want to know myself";

Test for diagnosis of achievement motivation [4, p. 72-76]. This test was the latest in the study and is intended to diagnose two generalized persistent personality motives: the motive for striving for success and the motive for avoiding failure. In doing so, it was assessed which of these two motives dominates the subject. The test is a questionnaire that has two forms: male (form A for 32 questions) and female (form B for 30 questions).

The calculation of correlation coefficients, regression analysis and all necessary intermediate data was carried out by computer processing, which was serviced by the IBM SPSS Statistics 20 software package.

\section{The results of the study of personality traits of an employee of the State Employment Service of Ukraine, as to their impact on the desire for self-development}

Let us analyze the results of the Big Five (5PFQ) methodology. First, we should pay attention to the significance of the main five factors presented in Figure 1. The minimum number of points scored for any major factor is 15 , the maximum number is 75 . Auxiliary factors (sub-factors) reveal the essence of the main, the maximum score of each is 15 . The auxiliary 
factors are unique and have two-sided significance. Conditionally grade points can be divided into high (51-75 points), medium (41-50 points) and low (15-40 points).

The first Extraversion factor is a scale that shows the level of extraversion - personality introversion. Figure 2 shows that SESU employees have an average level of extraversion (47 points), which tends to be high. The distribution of sub-factors is also visible. This indicates that the researchers are sociable, enjoy entertainment and collective activities, have a large circle of friends and acquaintances, feel the need to communicate with people who can talk and have a good time, seek idleness and entertainment, do not like to burden themselves with work or study, tend to acute, excitement, often risk, act impulsively, recklessly.

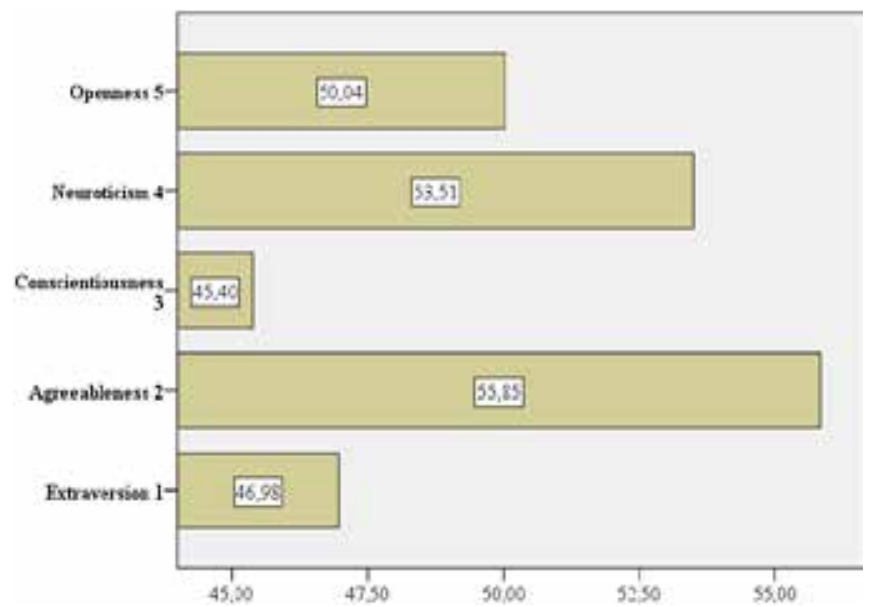

Figure 1. Results of the «Big Five» questionnaire (5PFQ)

These are individuals with weakened control over feelings and actions, so they are prone to inflammation and aggression. In work, as a rule, they focus on the speed of the task, from the monotonous activity they develop faster state of monotony, quickly burn out at work. Such people are sensitive to encouragement. feel cheerful in the evening and work better in the afternoon. 


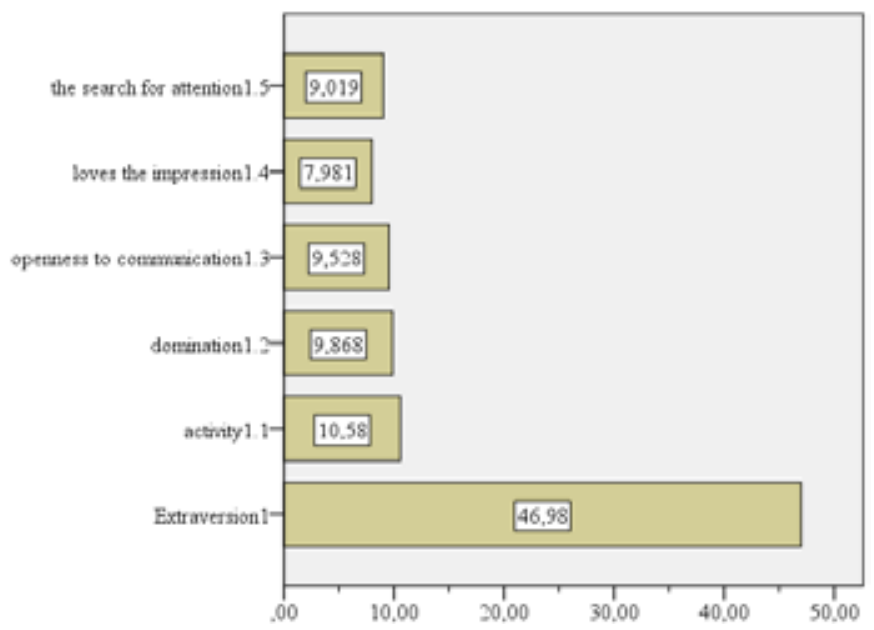

Figure 2. Results of the Extraversion factor

The second factor is "Agreeableness". It is a scale that shows the level of commitment - individuality. Figure 3 shows that the subjects scored high points 55.8. High values of the relevant factor determine the positive person's attitude to people. Such individuals feel the need to be close to other people. As a rule, they are kind and sensitive people, they understand other people well, feel personally responsible for other people's well-being, tolerate to other people's shortcomings. They are able to empathize, support collective actions and feel responsible for the common cause, conscientiously and responsibly carry out the assumed tasks. When interacting with others, such people try to avoid differences, do not like competition, prefer to cooperate with people rather than compete.

The third factor is "Conscientiousness". It is the level of self-control. As can be seen from Figure 4, SES staff have an average level of self-control (45), impulsiveness is present. The sub-factors describe such personality characteristics as: accuracy, perseverance, responsibility, restrainy and prudence. So such a person can rarely show willpower, trying not to complicate his/her life (looking for "an easy life"). This is a type of a personality, characterized by natural behavior, carelessness, tendency to ill-considered actions. Such a person may not be persistent in reaching the goal. It is likely that such a person, as a rule, will live one day, without looking into his/her future. 


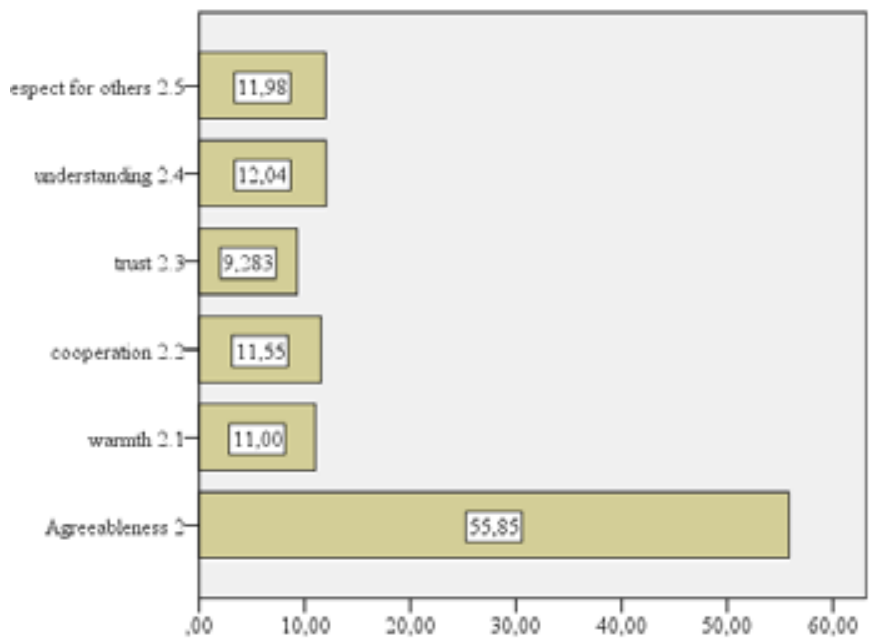

Figure 3. Results of the Agreeableness factor

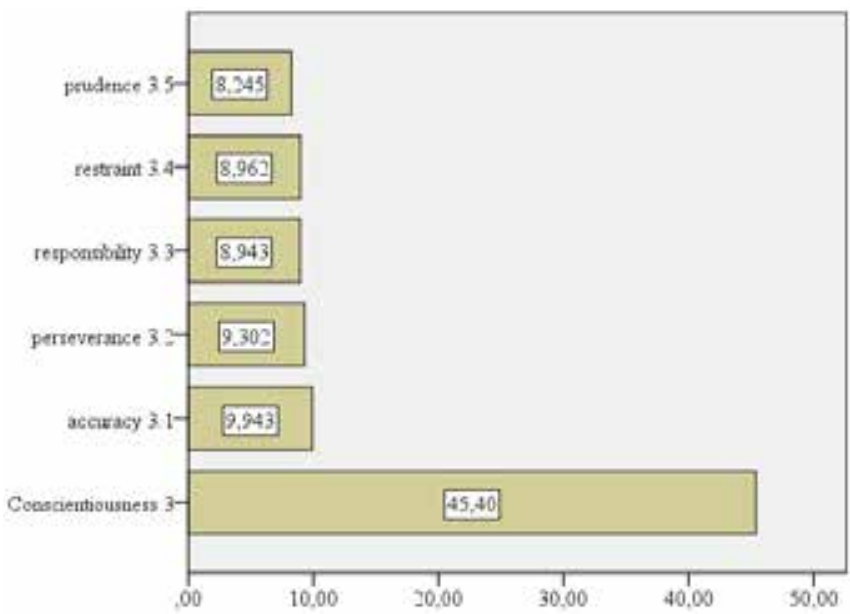

Figure 4. Results of the Conscientiousness factor

The fourth factor is "Neuroticism". It is emotional resilience or instability. This factor is pronounced high level (53) in the subjects (see Figure 5). High values for this factor characterize persons unable to control 
their emotions and impulsive trains. In behavior this is manifested as a lack of sense of responsibility, evasion of reality, capriciousness. Such people do worse in stressful situations in which they experience psychological stress. They tend to have a low self-esteem and are vulnerable to failure.

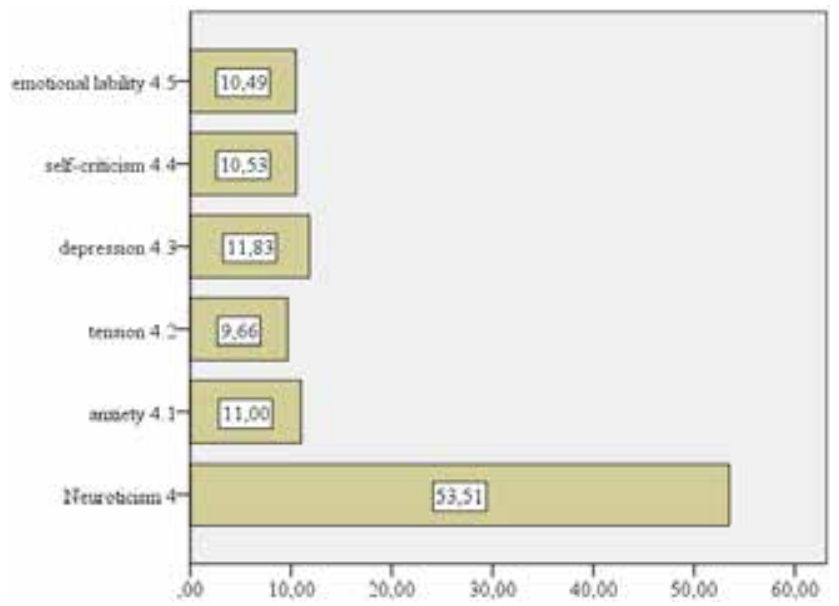

Figure 5. Results of the Neuroticism factor

The last fifth factor is "Openness" and determines expressiveness practicality. On this scale (see Figure 6), the subjects have scored 50 points, which corresponds to the average indicators, which tend to high ones (expressiveness). Such data can be interpreted as a light attitude to life. Personality gives the impression of carefree and irresponsible, and it is difficult for him/her to understand those who calculate their every step, give their strength to the creation of material well-being. The person is regarded as a game by life, performing the actions by which others see a manifestation of lightness. It is easy to learn for them, but systematic scientific activity is not serious enough, so such a person rarely achieves great success in science. But it's worth paying attention to the "behavioral flexibility" sub-factor. It is low to compared to others (7,9 points), so we can say that this personality is difficult to adapt to change.

Thus, we have obtained the personal profile of an employee of the State Employment Service of Ukraine. These sociable people are open to 


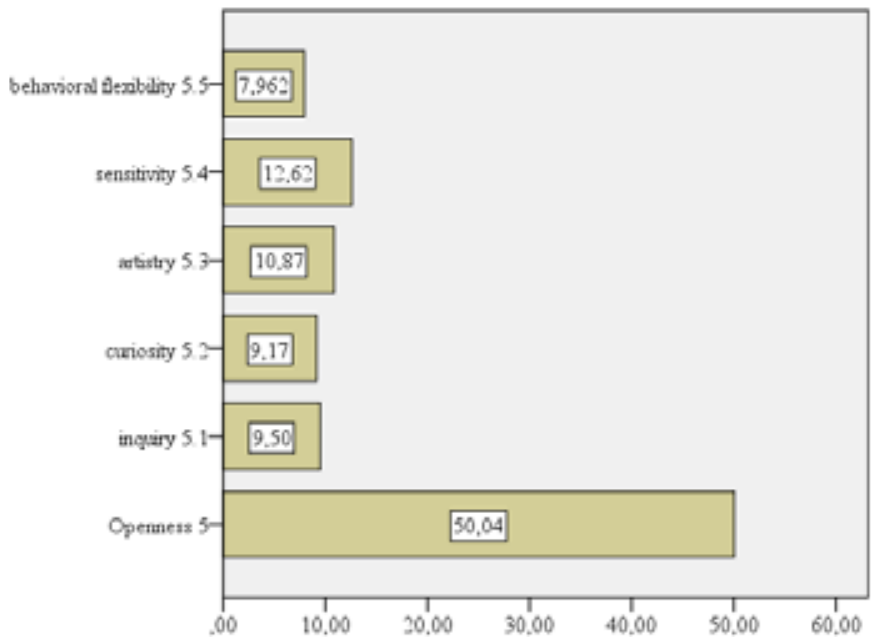

Figure 6. Results of the Openness factor

communicating with a light attitude to life. They are quite impulsive, that is why they work worse in stressful situations. They do not like to burden themselves with work, but they do it honestly. They do not like competition, tend not to be persistent in achieving their goal and may have low self-esteem. Easy to learn, but not sufficiently serious about systematic, sensitive research.

The next step in our study was to test the readiness of the subjects for self-development, and we have the following results. Table 3 shows that the median of the studied subjects on the scale $\mathrm{CDM}=3,67$, $\mathrm{WKM}=2,79$. Therefore, our subjects fall in the square "A". Respondents have opportunities for self-development, but they do not have the desire to know themselves. That is, the motivational component in the process of selfdevelopment is reduced. Such evidence indicates a low readiness for selfdevelopment. In this case, it should be remembered that professionalism in any field is achieved by finding their individual style of activity. And this, as we have already found, is impossible without self-knowledge. One of the reasons for such a low interest is the organization of work process in the State Employment Service of Ukraine. At present, all SESU employees work in accordance with the requirements of the Unified Technology for Serving the Unemployed Population in the Employment Centers of Ukraine (UTSUP). 
The UTSUP is, in essence, a description of the functional processes of providing services to unemployed citizens [19]. That is, employees have a clear step-by-step instruction of action with a registered time. On the one hand, it reduces the response time to jobless applications. and on the other hand, such clear execution of job descriptions eliminates the need for selfdevelopment, creativity, plasticity of behavior, etc., which, as we found in the theoretical analysis, is a necessary component in the professional activity of an employee (inspector) of the State Employment Service.

Table 3

Self-development of employees of the State Employment Service

\begin{tabular}{|l|c|c|}
\hline & WKM & CDM \\
\hline N Valid & 106 & 106 \\
$\quad$ Missed & 0 & 0 \\
Average & 2,79 & 3,67 \\
Med & 3,00 & 4,00 \\
Dispersion & 0,85 & 1,92 \\
\hline
\end{tabular}

Note: $\mathrm{WKM}=\mathrm{I}$ want to know myself, CSD $=$ I can self-develop $1=$ low level, $6=$ high level

Finally, let us analyze the motivation for the achievement of the subjects. Achievement motivation in subjects (Table 4), is below average: mean $=93$, median $=85$ out of 210 . These results are generally correlated with low scores on the "Want to know yourself" scale and indicate low motivation to achieve. Also, the overwhelming number of respondents is driven by the motive of avoiding failure, not the motive of achievement success. With this level of achievement motivation, it can be predicted that the quality of the workflow of the subjects decreases.

Table 4

Indicator of motivation of achievement

\begin{tabular}{|l|c|}
\hline N $\quad$ Valid & 106 \\
Missed & 0 \\
The average & 93,37 \\
Median & 85,00 \\
Minimum & 57,00 \\
Maximum & 163,00 \\
\hline
\end{tabular}




\section{Correlation analysis of the research}

Having the results of the empirical research, one can proceed to the correlation analysis. As Table 5 shows, the correlation analysis confirms that there is a two-way positive relationship between the Motivation of Achievement and Want-to-Know scales. A more detailed and concise overview of the key correlations identified by this study can be seen in Figure 1. Significance level is $(\mathrm{p}<01), \mathrm{R}=47$, and can be interpreted as strong enough for this study. That is, with an increase in the achievement motivation indicator, in $47 \%$ of cases, the "I want to know myself" indicator will tend to increase. Conversely, with an increase in the "I want to know myself" indicator, in $47 \%$ of cases, the "Motivation to Achieve" indicator will also tend to increase as well. As to the personal dimensions, the Motivation of Achievement scale has a two-way positive relationship with the following factors: Conscientiousness $\mathrm{R}=34$ and Openness $\mathrm{R}=30$.

Table 5

Correlation analyze

\begin{tabular}{|l|c|c|c|c|c|c|c|}
\hline \multicolumn{1}{|c|}{ Variable } & $\begin{array}{c}\text { Achieve- } \\
\text { ment } \\
\text { motivation }\end{array}$ & $\mathbf{W K M}$ & $\mathbf{1}$ & $\mathbf{2}$ & $\mathbf{3}$ & $\mathbf{4}$ & $\mathbf{5}$ \\
\hline $\begin{array}{l}\text { Achievement } \\
\text { motivation }\end{array}$ & 1 &, $475^{* *}$ &, $197^{*}$ &,- 041 &, $336^{* *}$ &,$- 207^{*}$ &, $296^{* *}$ \\
\hline WKM &, $475^{* *}$ & 1 &, 151 &, 064 &, $481^{* *}$ &,- 077 &, $648^{* *}$ \\
\hline Extraversion 1 &, $197^{*}$ &, 151 & 1 &,$- 391^{* *}$ &,- 143 &,$- 571^{* *}$ &,$- 211^{*}$ \\
\hline Agreeableness 2 &,- 041 &, 064 &,$- 391^{* *}$ & 1 &, $554^{* *}$ &, $294^{* *}$ &, $558^{* *}$ \\
\hline $\begin{array}{l}\text { Conscienti- } \\
\text { ousness 3 }\end{array}$ &, $336^{* *}$ &, $481^{* *}$ &,- 143 &, $554^{* *}$ & 1 &, $419^{* *}$ &, $427^{* *}$ \\
\hline Neuroticism 4 &,$- 207^{*}$ &,- 077 &,$- 571^{* *}$ &, $294^{* *}$ &, $419^{* *}$ & 1 &, 010 \\
\hline Openness 5 &, $296^{* *}$ &, $648^{* *}$ &,$- 211^{*}$ &, $558^{* *}$ &, $427^{* *}$ &, 010 & 1 \\
\hline
\end{tabular}

Note: WKM =I want to know myself, ${ }^{*} \mathrm{p}<05 .,{ }^{* *} \mathrm{p}<01$.

That is, with an increase the "Motivation of Achievement" indicator, the "Conscientiousness" will tend to increase in $34 \%$ of the cases and "Openness" in 30\% (and vice versa). We also have a weak positive relationship with the factor Extraversion $\mathrm{R}=20$. We have a weak negative relationship with the factor Neuroticism $\mathrm{R}=-20$ and Agreeableness 
$\mathrm{R}=-0,4$. But the statistical significance of such correlation is very low and does not need interpretation.

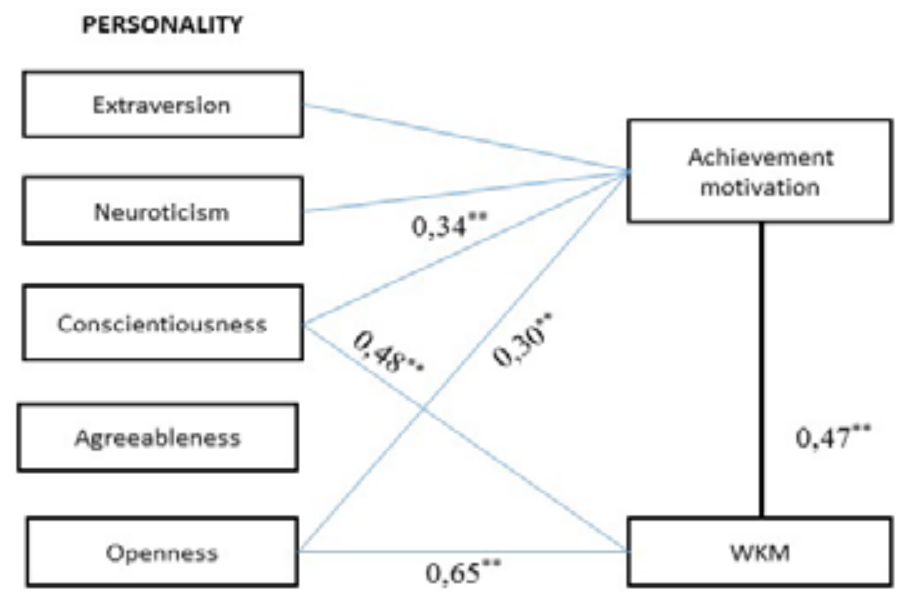

Figure 7. Key correlational

As to the relationship between the "I want to know myself" scale and personal dimensions, it is positive and strong with the Openness factor $\mathrm{R}=$ 65 . This means that in $65 \%$ of cases, with an increase in the desire to know oneself, the expression of expressiveness will increase, namely: interest, curiosity, artistry, sensitivity and plasticity of behavior. With all other factors, we have a small positive and negative relationship.

\section{Conclusions}

Self-motivation plays an important role in personal development. In the context of classical and modern acmepsychological studies the key role of the theoretical and methodological foundations of the study of the nature of mediation of integrational acmeological phenomena peculiar structure of human individuality has been shown. It is important for the optimization of acmeological development of the person, prevention sometimes harmful to him/her emotional state and the operating tension, stress, and destruction of personality, psychosomatic disorders. These issues are understudied, especially from the point of view of perspective of research of the employees 
of the State Employment Service organizations. It shows the importance of the topic for future research.

In accordance to the stated goal, the research has showed that the employees of the State Employment Service of Ukraine have little need for personal development. The motivational component is reduced - they have the opportunity to develop themselves, but do not want it. Such their position significantly $(\mathrm{R}=47)$ influences on achievement motivation, it is lower than average. Also, the overwhelming number of respondents is driven by the motive of avoiding failure, not the motive for success. With this level of achievement motivation, it can be predicted that the quality of the workflow of the subjects decreases.

The personality profile of an employee of the State Employment Service of Ukraine provides for such personality traits as: sociability, openness to communication, easy attitude to life, impulsiveness. They do not like competition, tend not to be persistent in achieving their goal and may have low self-esteem. They are insecure in stressful situations and sensitive to encouragement. They have personality who difficult to adapt to change.

Such an indicator as achievement motivation is significantly related to personality factors: Conscientiousness and Openness. That is, the aspiration for success requires personal qualities of the individual such as: persistence, responsibility, self-control, predictability, interest, curiosity, artistry, sensitivity and plasticity of behavior. Interestingly, that our subjects have showed a low self-control score and an average Expression score. This, in turn, explains their low desire for their self-development.

In addition, it is necessary to understand that self-motivation also plays an important role. In the context of classical and modern acmepsychological studies the key role of the theoretical and methodological foundations of the study of the nature of mediation of integrational acmeological phenomena peculiar structure of human individuality has been shown. It is important for the optimization of acmeological development of the person, prevention sometimes harmful to him/her emotional state and the operating tension, stress, and destruction of personality, psychosomatic disorders. These issues are understudied, especially from the point of view of perspective of research of personnel reserve of the State Employment Service organizations. It also shows the importance of the topic for future research. 
As a person's personal qualities, norms, roles, rules of behavior, values system are developed and formed throughout his/her life, it is important that people who provide assistance to the unemployed are motivated to develop themselves. This idea is the key-note to further study the factors of personal development of the personnel reserve of the State Employment Service of Ukraine. It is also supposed to develop a personal development program for the personnel reserve of the State Employment Service of Ukraine.

\section{References:}

1. Beausaert S., Segers M., Gijselaers W. (2011). The Personal Development Plan Practice Questionnaire: The development and validation of an instrument to assess the employees perception of personal development plan practice. International Journal of Training and Development, vol. 15, no. 4, pp. 249-270.

2. Bodrov V.A. (2001). Psykholohyia professyonalnoi pryhodnosty [Occupational Psychology]. Moscow: PERSE. (in Russian)

3. Dmytriiev-Zarudenko V.V. (2010). Moduli kompetentnosti v praktytsi diialnosti derzhavnoi sluzhby zainiatosti. [Models of competence in the practice of state employment service]. Rynok pratsi ta zainiatist naselennia. Sotsiolohopsykholohichni aspekty pratsi ta zainiatosti, no. 3, pp. 26-30.

4. Fetyskyn N.P., Kozlov V.V., Manuilov H.M. (2002). Sotsyalnopsykholohycheskaia dyahnostyka razvytyia lychnosty y malukh hrupp [Sociopsychological diagnosis of the development of personality and small groups]. Moscow: Ynstytuta Psykhoterapyy, pp. 72-76.

5. Fryzen M.A. (2016). Psykholohycheskaia hotovnost k samorazvytyiu u mladshykh podrostkov [Psychological readiness for self-development in younger adolescents]. Materials of the XXXIII Krashennyk readings. Kamch. PetropavlovskKamchatskyi: Kamch. kraevaia nauch. b-ka ym. S.P. Krashenynnykova, pp. 293-296.

6. Honcharuk N. (2003). Formuvannia yakostei kerivnyka u derzhavnomu upravlinni [Formation of the qualities of a leader in public administration]. Visn. NADU, no. 3, pp. 137-147.

7. Hughes J., Youngson S. (2009). Personal Development and Clinical Psychology. West Sussex: Blackwell Publishing. (in United Kingdom)

8. Kalenychenko K.M. (2018). Intelektualizatsiia pratsi, yak psykholohichna peredumova osobystisnoho rozvytku osib, shcho perenavchaiutsia u Derzhavnii sluzhbi zainiatosti [Labor intellectualization as a psychological precondition for personal development of trained persons in the State Employment Service]. Naukovyi visnyk Khersonskoho derzhavnoho universytetu. Seriia «Psykholohichni nauky», vol. 2, no. 1, pp. 31-45. Retrieved from: http://pj.kherson.ua/file/2018/ psychology_01/ukr/part_2/7.pdf (accessed 18 September 2019).

9. Khromov A.B. (2000). Piatyfaktornui oprosnyk lychnosty: Uchebnometodycheskoe posobye [Five-Factor Personality Questionnaire: A Training Manual]. Kurhan: Kurhanskoho hos. Unyversyteta. (in Russian) 
10. Kohan L.N. (1981). Vsebichnyi rozvytok osobystosti i kultura [Comprehensive personality development and culture]. Moscow: Znanye. (in Russian)

11. Kon Y.S. (1984). V poyskakh sebia. Lychnost y eё samosoznanye [In search of myself. Personality and its identity]. Moscow: Polytyzdat. (in Russian)

12. Kopets L.V. (2007). Psykholohiia osobystosti [Personality psychology]. Kyiv: Vydavnychyi dim "Kyievo-Mohylianska akademiia". (in Ukrainian)

13. Murray H.A. (1938). Explorations in Personality. New York: Oxford University Press. (in USA)

14. Nyniuk I.I. (2005). Profesionalizm derzhavnykh sluzhbovtsiv: sutnist, stan ta osoblyvosti formuvannia [Professionalism of civil servants: nature, condition and peculiarities of formation]. (PhD Thesis), Kyiv: Nats. akad. derzh. upr. pry Prezydentovi Ukrainy.

15. Raven D. (2002). Kompetentnost v sovremennom obshchestve: vuyavlenye, razvytye y realyzatsyia [Competence in modern society: identification, development and implementation]. Moscow: Kohyto-Tsentr. (in Russian)

16. Piekhota O.M. (2009). Indyvidualnist uchytelia. Teoriia i praktyka [The personality of the teacher. Theory and Practice]. Mykolaiv: TOV Firma "Ilion", pp. 30-33.

17. Thomas T. (2014). Cutting Edge to Success. Personal Development and Time Management Skills that will change your Life. Imprint: Lulu Publishing Services. Retrieved from: https://books.google.com.ua/books?id= hOVeCAAAQBAJ\&printsec $=$ frontcover\&redir_esc $=\mathrm{y} \# \mathrm{v}=$ onepage \& $\mathrm{q} \& \mathrm{f}=$ false (accessed 12 August 2019).

18. Tamminga I., Elsbeth de Boer (2018). Employees desire for personal development in the front office of the InterContinental Miami, Research in Hospitality Management (electronic journal), vol. 7, no. 2, pp. 99-103. Retrieved from: https://doi.org/10.1080/22243534.2017.1444717 (accessed 8 August 2019).

19. Tulenkov M.V. (ed.) (2010). Rynok pratsi ta zainiatist naselennia: problemy teorii ta vyklyky praktyky [Labor market and employment: problems of theory and challenges of practice]. Kyiv: IPK DSZU.

20. Qosja, E. (2015). Motivation Factors Impacting the Civil Servant Performance in Local Public Administration in Kosovo, Journal of US-China Public Administration, vol. 12, no. 1, pp. 15-24. Retrieved from: http://www.davidpublisher.org/Public/uploads/Contribute/553a06a2cfd41.pdf (accessed 21 March 2018).

21. Vlasova O.I. (2011). Metodyka vykladannia psykholohii [Methodology of teaching psychology]. Kyiv: Heoprynt. (in Ukrainian)

22. Zakon Ukrainy (2007). Pro Osnovni zasady rozvytku informatsiinoho suspilstva v Ukraini na 2007-2015 roky [Law of Ukraine: About the Fundamentals of Information Society Development in Ukraine for 2007-2015], Kyiv. Retrieved from: http://zakon5.rada.gov.ua/laws/show/537-16 (accessed 3 March 2017). 